\title{
The elevated preoperative platelet-to- lymphocyte ratio predicts poor prognosis in breast cancer patients
}

\author{
S Krenn-Pilko ${ }^{1,6}$, U Langsenlehner ${ }^{2,6}$, E-M Thurner ${ }^{1}$, T Stojakovic $^{3}$, M Pichler ${ }^{4}$, A Gerger ${ }^{5}$, K S Kapp ${ }^{1}$ \\ and T Langsenlehner ${ }^{\star}, 1$
}

${ }^{1}$ Department of Therapeutic Radiology and Oncology, Medical University of Graz, Auenbruggerplatz 32, 8036 Graz, Austria; ${ }^{2}$ Division of Internal Medicine, Outpatient Department Graz, Graz, Austria; ${ }^{3}$ Clinical Institute of Medical and Chemical Laboratory Diagnostics, Medical University of Graz, Graz, Austria; ${ }^{4}$ Department of Experimental Therapeutics, The University of Texas MD Anderson Cancer Center, Houston, TX, USA and ${ }^{5}$ Division of Clinical Oncology, Department of Medicine, Medical University of Graz, Graz, Austria

Background: The elevation of the platelet-to-lymphocyte ratio (PLR), an easily applicable blood test based on platelet and lymphocyte counts has been associated with poor prognosis in patients with different types of cancer. The present study was aimed to investigate the prognostic significance of the preoperative PLR in a large cohort of breast cancer patients.

Methods: Data from 793 consecutive non-metastatic breast cancer patients, treated between 1999 and 2004, were evaluated retrospectively. The optimal cutoff values for the PLR were calculated using receiver operating curve analysis. Cancer-specific survival (CSS), overall survival (OS) as well as distant metastasis-free survival (DMFS) were assessed using the Kaplan-Meier method. To evaluate the independent prognostic significance of PLR, multivariable Cox regression models were applied for all three different end points.

Results: Univariable analysis revealed a significant association between the elevated preoperative PLR and CSS (hazard ratio (HR): $2.75,95 \%$ confidence interval $(\mathrm{Cl}): 1.57-4.83, P<0.001)$ that remained statistically significant in multivariable analysis (HR: $2.03,95 \%$ $\mathrm{Cl}: 1.03-4.02, P=0.042)$. An increased PLR was also significantly associated with decreased OS in univariable (HR: $2.45,95 \% \mathrm{Cl}$ : 1.43-4.20, $P=0.001$ ) and in multivariable analysis (HR: 1.92, 95\% Cl: 1.01-3.67, $P=0.047$ ). Furthermore, univariable analysis showed a significant impact of increased PLR on DMFS (HR: 2.02, 95\% Cl: 1.18-3.44, $P=0.010$ ). Subgroup analysis revealed significant associations of the elevated PLR on the primary end point CSS for all breast cancer subtypes. This association retained its significance in multivariable analysis in patients with luminal B tumours (HR: 2.538,95\% Cl: 1.043-6.177, $P=0.040$ ).

Conclusions: In this study, we identified the preoperative PLR as an independent prognostic marker for survival in breast cancer patients. Independent validation of our findings is needed.

Breast cancer is the most commonly diagnosed cancer in woman worldwide and its incidence is increasing owing to mammographic screening and an ageing population. Postmenopausal hormone replacement therapy, Western-style diet, obesity, and consumption of alcohol and tobacco contribute to the rising incidence of breast cancer. Because of improved treatment and earlier detection, the mortality rate has decreased in recent years in most Western countries; however, breast cancer is still the third leading cause of

\footnotetext{
*Correspondence: Associate Professor T Langsenlehner; E-mail: tanja.langsenlehner@medunigraz.at
}

${ }^{6}$ These authors contributed equally to this work. 
cancer-related death in Europe and the United States (Ferlay et al, 2012).

The prognosis of breast cancer patients depends on biological characteristics of the cancer and on patient and treatment characteristics. Established prognostic and predictive factors are age, tumour size, grade, nodal status, and endocrine/Her2neu receptor status. These parameters can be integrated into prognostic models that allow a relatively accurate estimation of the probability of recurrence and death from breast cancer (Kraeima et al, 2013).

In addition, a large number of translational research studies have revealed an association of various molecular biomarkers with clinical outcome in breast cancer. Molecular predictors of prognosis (for example, the Amsterdam 70 gene signature, Mammaprint, or the 16-gene Recurrence Score, Oncotype Dx) may be used to gain additional prognostic and/or predictive information, but their relevance for integration into current clinical practice is still under investigation (Albain et al, 2010; Saghatchian et al, 2012; Drukker et al, 2013). In addition, high costs, lack of standardisation and regional availability limit their application in routine clinical practice.

Tumour progression and metastasisation comprise a cascade of steps that involve the interaction between the tumour and the hostderived stromal microenvironment, which includes factors that support angiogenesis and inflammation (Balkwill and Mantovani, 2001; Coussens and Werb, 2002). Recent data have expanded the concept that the systemic inflammatory response that is usually measured by surrogate blood-based parameters, such as C-reactive protein, neutrophil, or platelet count, has an important role in the progression of several solid tumours (Coussens and Werb, 2002; Mantovani et al, 2008; Roxburgh and McMillan, 2012; Dethlefsen et al, 2013; Szkandera et al, 2013).

Systemic inflammation is associated with the release of several pro-inflammatory mediators such as interleukin (IL)-1, IL-3, and IL-6 that are known to stimulate megakaryocyte proliferation leading to thrombocytosis. Platelet aggregation and degranulation along with the consequent release of platelet-derived proangiogenic mediators have been suggested as the important determinant of tumour growth (Klinger and Jelkmann, 2002). In addition, a number of immunologic mediators, most notably IL-10 and transforming growth factor- $\beta$ are released, which can result in a significant immunosuppressive effect with consequent impaired lymphocyte function and reduced lymphocyte counts (SalazarOnfray et al, 2007).

Pre-therapeutic indices of systemic inflammation have been suggested to provide prognostic information in various cancer entities. Among these inflammatory parameters, the platelet-tolymphocyte ratio (PLR) has been proposed as an easily accessible and reliable marker to predict cancer prognosis (Smith et al, 2008; Koch et al, 2009; Smith et al, 2009; Asher et al, 2011; Proctor et al, 2011; Carruthers et al, 2012; Kwon et al, 2012; Raungkaewmanee et al, 2012; Roxburgh and McMillan, 2012; Liu et al, 2013).

Cumulating evidence suggests that a high PLR might represent an independent adverse prognostic factor in ovarian cancer (Asher et al, 2011; Raungkaewmanee et al, 2012), colorectal cancer (Kwon et al, 2012; He et al, 2013), advanced gastric cancer (Lee et al, 2012) as well as in pancreatic cancer (Smith et al, 2009). However, data regarding the prognostic significance of the PLR in breast cancer are sparse, and currently available data from small scale studies provide conflicting results about its prognostic significance with regard to different clinical end points in breast cancer patients (Seretis et al, 2012; Azab et al, 2013).

The purpose of our study was to evaluate the effect of the preoperative PLR on cancer-specific survival (CSS), overall survival (OS), and distant metastases-free survival (DMFS) in a large cohort of non-metastatic breast cancer patients in order to further clarify the prognostic significance of the PLR for breast cancer.

\section{MATERIALS AND METHODS}

Subjects. A total of 793 patients with histologically confirmed breast cancer were included in this retrospective study. The data set included all female patients with non-metastasised breast cancer who had been treated and/or had been included in the breast cancer surveillance programme at the Division of Clinical Oncology and the Department of Therapeutic Radiology and Oncology, Medical University of Graz from December 1999 to June 2004. Clinical and histopathological features were retrospectively obtained from the patient's history. In 81 patients (10\%), a modified radical mastectomy was performed; the remaining patients were treated with breast conserving surgery and adjuvant radiotherapy. The preoperative blood cell count was obtained within 3 days before surgery. Adjuvant chemotherapy was administered in 93 patients (12\%), adjuvant hormonal treatment in 378 patients (48\%), and 202 patients (26\%) were treated with adjuvant chemotherapy and hormonal therapy.

Follow-up investigations were performed in regular intervals (3-month intervals in years $1-3,6$-month intervals in years $4-5$, and 12-month intervals in years 6-10 after diagnosis) and included clinical examination, laboratory tests including CEA and carbohydrate antigen 15-3, radiological assessment (mammography and breast ultrasound, liver scan or ultrasound and chest X-ray), and gynaecological examination. Loss to follow-up rate was $4.3 \%$ after 3 years and $7.1 \%$ after 5 years. This study has been approved by the Institutional Review Board of the Medical University of Graz. All participants were Caucasians.

Statistical analysis. The primary end point was cancer-specific survival (CSS) defined as the time from breast cancer diagnosis to the date of patients' breast cancer-related death. The secondary end points included OS calculated from the time of diagnoses to death of any cause, and DMFS calculated from the date of diagnosis to the date of breast cancer metastases.

The PLR was calculated as the absolute platelet count measured in $\times 10^{9} 1^{-1}$ divided by the absolute lymphocyte count measured in $\times 10^{9} 1^{-1}$. The neutrophil-to-lymphocyte ratio (NLR) was calculated as the absolute neutrophil count measured in $\times 10^{9} 1^{-1}$ divided by the absolute lymphocyte count measured in $\times 10^{9} 1^{-1}$. The ideal cutoff value for the PLR and NLR was determined applying receiver operating curve analysis as previously published (Absenger et al, 2013).

The relationship between the PLR and other clinico-pathological features was studied by $\chi^{2}$-test. Patients' clinical end points were calculated using the Kaplan-Meier method and compared by the log-rank test. Backward stepwise multivariable Cox proportion analysis was performed to determine the influence of potential confounders such as age, pathologic tumour stage, grade, lymph node involvement, oestrogen receptor (ER), progesterone receptor (PR), and HER2 status on CSS, OS, and DMFS. Hazard ratios (HRs) estimated from the Cox analysis were reported as relative risks with corresponding 95\% confidence intervals (CIs). All statistical analyses were performed using the Statistical Package for Social Sciences version 20.0 (SPSS Inc., Chicago, IL, USA). A twosided $P<0.05$ was considered statistically significant.

\section{RESULTS}

A total of 793 female patients with histologically confirmed breast cancer were included in the present analysis. The median age at the time of diagnosis was $57.9 \pm 12.2$ years.

Baseline patient characteristics are shown in Table 1. Patients have been classified into the subtypes luminal A, luminal B, Her2, and basal like according to the St Gallen recommendations 


\begin{tabular}{|c|c|}
\hline & Patient characteristics, $n$ (\%) \\
\hline$n$ & 793 \\
\hline \multicolumn{2}{|c|}{ Age at diagnosis (years) } \\
\hline$\leqslant 60$ & 410 (51.7\%) \\
\hline$>60$ & $383(48.3 \%)$ \\
\hline \multicolumn{2}{|c|}{ Tumour stage } \\
\hline T1 & $450(56.7 \%)$ \\
\hline T2 & 178 (22.4\%) \\
\hline T3 & 102 (12.9\%) \\
\hline T4 & 38 (4.8\%) \\
\hline Missing data & $25(3.2 \%)$ \\
\hline \multicolumn{2}{|c|}{ Lymph node involvement } \\
\hline NO & $454(57.3 \%)$ \\
\hline N1 & $207(26.1 \%)$ \\
\hline N2 & $79(10.0 \%)$ \\
\hline N3 & 45 (5.7\%) \\
\hline Missing data & $8(1 \%)$ \\
\hline
\end{tabular}

\section{AJCC stage}

\begin{tabular}{|l|c|}
\hline IA & $316(39.8 \%)$ \\
IB & $1(0.1 \%)$ \\
IIA & $164(20.7 \%)$ \\
IIB & $113(14.2 \%)$ \\
IIIA & $98(12.4 \%)$ \\
IIIB & $33(4.2 \%)$ \\
IIIC & $43(5.4 \%)$ \\
Missing data & $24(3 \%)$ \\
\hline
\end{tabular}

Tumour grade

\begin{tabular}{|l|c|}
\hline $\mathrm{G} 1$ & $57(7.2 \%)$ \\
$\mathrm{G} 2$ & $383(48.3 \%)$ \\
$\mathrm{G} 3+\mathrm{G} 4$ & $350(43.9 \%)$ \\
Missing data & $3(0.4 \%)$
\end{tabular}

\section{Molecular subtype}

\begin{tabular}{|l|c|}
\hline Luminal A & $369(46.5 \%)$ \\
Luminal B & $251(31.7 \%)$ \\
Basal like & $70(8.8 \%)$ \\
Her2 & $30(3.8 \%)$ \\
Missing data & $73(9.2 \%)$ \\
\hline
\end{tabular}

Abbreviations: AJCC stage $=$ American Joint Committee on Cancer stage; $n=$ number of patients.

published by Goldhirsch et al (2011). A total of 369 patients (46.5\%) have been classified into luminal A, 251 patients (31.7\%) into luminal B, 30 patients (3.8\%) into the HER2-positive subtype, and 70 patients $(8.8 \%)$ into the basal-like subtype. Classification was possible in 720 patients (91\%). Determination of ER, PR, and HER2 receptor status revealed ER expression in 623 cases (78.6\%), PR expression in 483 cases (60.9\%), and Her2 overexpression in 85 cases $(10.7 \%)$. HER2 status was generally determined using the HercepTest. A negative assay was reported with 0 and $1+$ staining, whereas $3+$ was reported as positive; in case of a $2+$ level of staining, a confirmatory testing by fluorescence in situ hybridisation was performed.

The mean platelet count was $271.2 \pm 69.6$, the mean lymphocyte count was $1.7 \pm 0.6$, and the mean PLR was $181.1 \pm 131.0$. In 747 patients $(94.2 \%)$, the preoperative PLR was available.

Applying the criteria mentioned above, we determined a cutoff value of 292 for the PLR to be optimal to discriminate between patients' CSS that prompted us to select 292 as the optimal cutoff value for all subsequent analyses to differentiate between low $(<292)$ and high $(\geqslant 292)$ PLR. Overall, there were 699 patients with a low PLR and 48 patients with a high PLR.

A high PLR significantly correlated with lymph node involvement, high tumour grade, and ER-negative tumours (all $P<0.05)$, but not with age, advanced T stage, PR status, or Her2 overexpression.

Median follow-up time was $98 \pm 29.2$ months. Of the 793 breast cancer patients, 167 (21.1\%) developed metastatic disease, 116 (14.6\%) died due to disease progression. Overall, 136 patients (17.2\%) died for any cause. Figures 1, 2 and 3 show the KaplanMeier curves for CSS, OS, and DMFS and reveal that a high PLR is a consistent factor for poor prognosis in breast cancer patients $(P<0.01$ for all three tested end points, log-rank test).

Univariable analysis revealed a significant impact of a high PLR on CSS. In our multivariable analysis that included age, tumour stage, lymph node involvement, oestrogen and PR status, Her2 status, and PLR, the PLR was identified as an independent prognosticator of poor outcome for patients' CSS (HR: 2.03, 95\% CI: $1.03-4.02 ; P=0.042$, Table 1). Furthermore, multivariable analysis showed a significant association of advanced $\mathrm{T}$ stage and $\mathrm{N}$ stage with poor CSS (Table 1). Regarding OS, a high PLR was identified as an independent prognostic factor for poor survival (HR: 1.92 , 95\% CI: $1.01-3.67, P=0.047$, Table 2 ). In addition, tumour stage and lymph node stage were independently associated with OS.

Univariable analysis showed a significant association between increased PLR and the occurrence of distant metastases (HR: 2.02, 95\% CI: $1.18-3.44, P=0.010)$. In multivariable analysis, the PLR did not remain a significant prognosticator of DMFS, whereas a significant impact of advanced $\mathrm{T}$ stage and lymph node involvement on poor DMFS was found (Table 3).

Internal validation has been performed by randomly splitting the data set into two subsets. In subgroup 1 ( $n=391$ patients), the HR for CSS was 2.588 (95\% CI: 1.103-6.069) and in subgroup 2 ( $n=402$ patients), the HR for CSS was 2.867 (95\% CI: 1.356-6.061).

Subgroup analysis revealed significant associations of the elevated PLR on the primary end point CSS for all breast cancer subtypes (Tables 3 and 4). This association retained its significance in multivariable analysis in patients with luminal B tumours (HR: $2.538,95 \%$ CI: $1.043-6.177, P=0.040$ ). In this breast cancer subgroup, the PLR turned out to be superior in terms of the prognostic impact compared with age, $\mathrm{T}$ status, and $\mathrm{N} 1$ and $\mathrm{N} 1$ status.

In the present cohort, a total of 120 patients (15\%) did not receive any adjuvant systemic therapy. In univariable analysis, the PLR was significantly associated with CSS among these patients (HR: 4.449, 95\% CI: 1.612-12.27, $P=0.004$ ). However, multivariable analysis did not show a significant effect of an elevated PLR on CSS (HR: $2.745,95 \%$ CI: $0.728-10.34, P=0.136$ ).

Applying the criteria mentioned above, the cutoff value for the NLR to be optimal to discriminate between patients' CSS was 2.5. Overall, there were 299 patients $(37.7 \%)$ with a low NLR $(<2.5)$ and 448 patients $(56.5 \%)$ with a high NLR $(\geqslant 2.5)$. In univariable analysis, we detected a significant association between an elevated NLR and cancer-specific survival (HR: 1.514, 95\% CI: 1.008-2.275, $P=0.046)$. In multivariable analysis, a significant impact of NLR on CSS was not detected (HR: 1.247, 95\% CI: 0.811-1.918, $P=0.315)$.

\section{DISCUSSION}

Despite recent progress in the identification of genetic, epigenetic, and common molecular alterations, the routine diagnostic and 


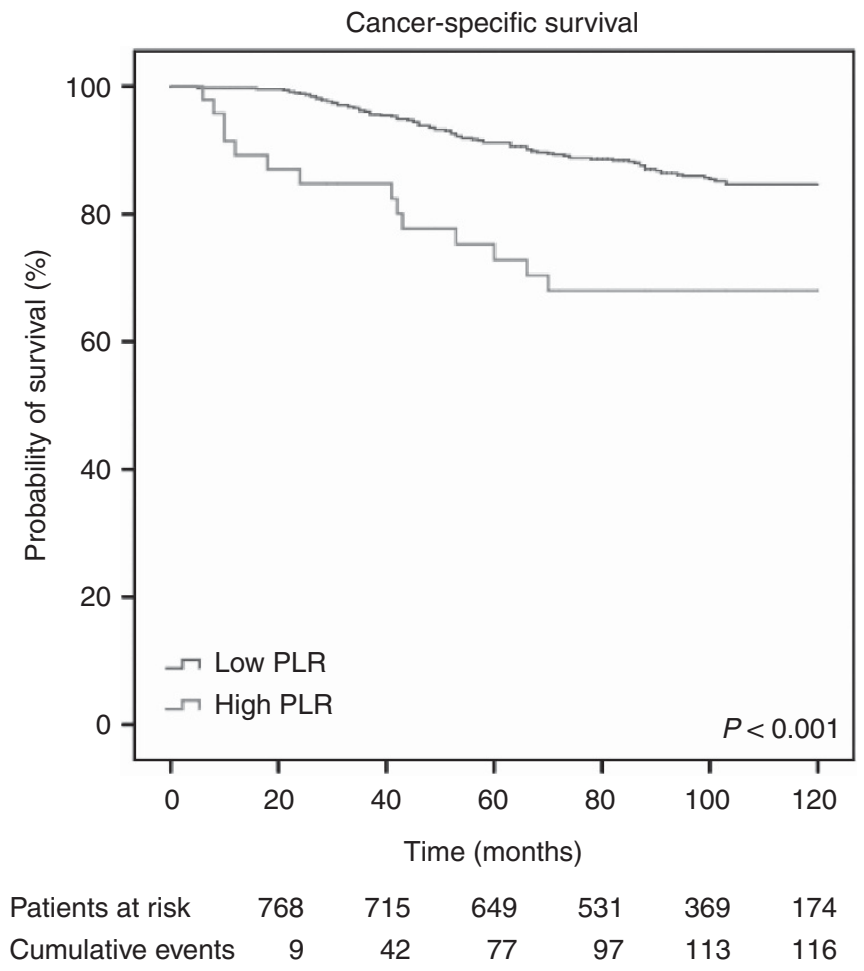

Figure 1. Kaplan-Meier curves for CSS of breast cancer patients categorised by the PLR.

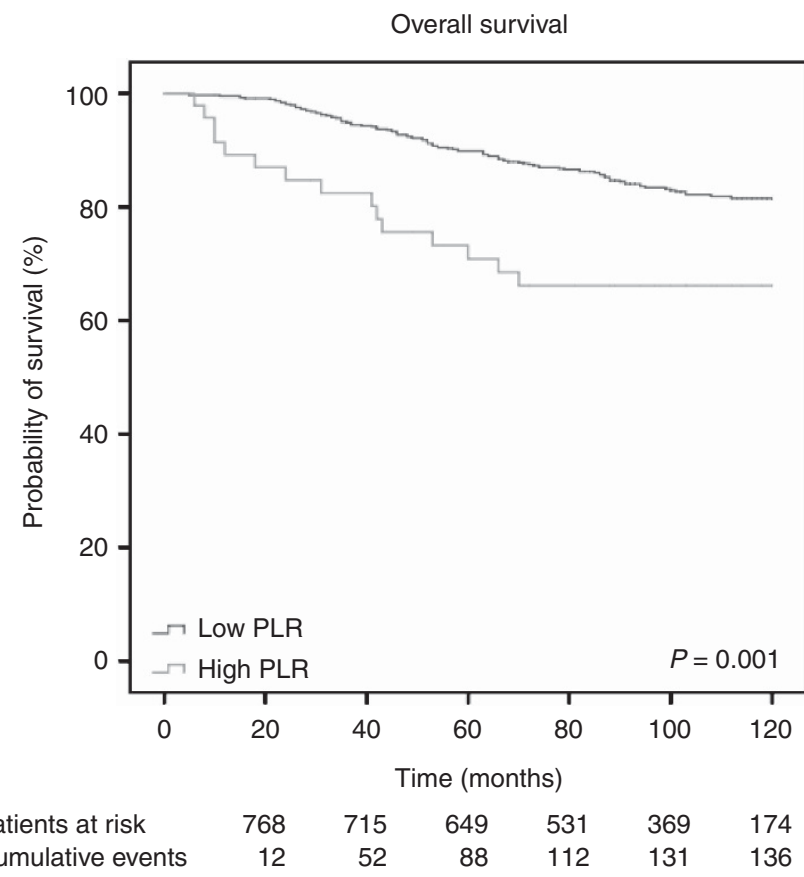

Figure 2. Kaplan-Meier curves for OS of breast cancer patients categorised by the PLR.

prognostic assessment of breast cancer currently relies on pathological tissue examination and traditional clinico-pathological prognostic variables (Blamey et al, 2007). Regularly used blood-based parameters, such as platelet or lymphocyte counts, are relatively easy to assess without additional laborious efforts, making them attractive parameters for an improved individualised risk assessment.

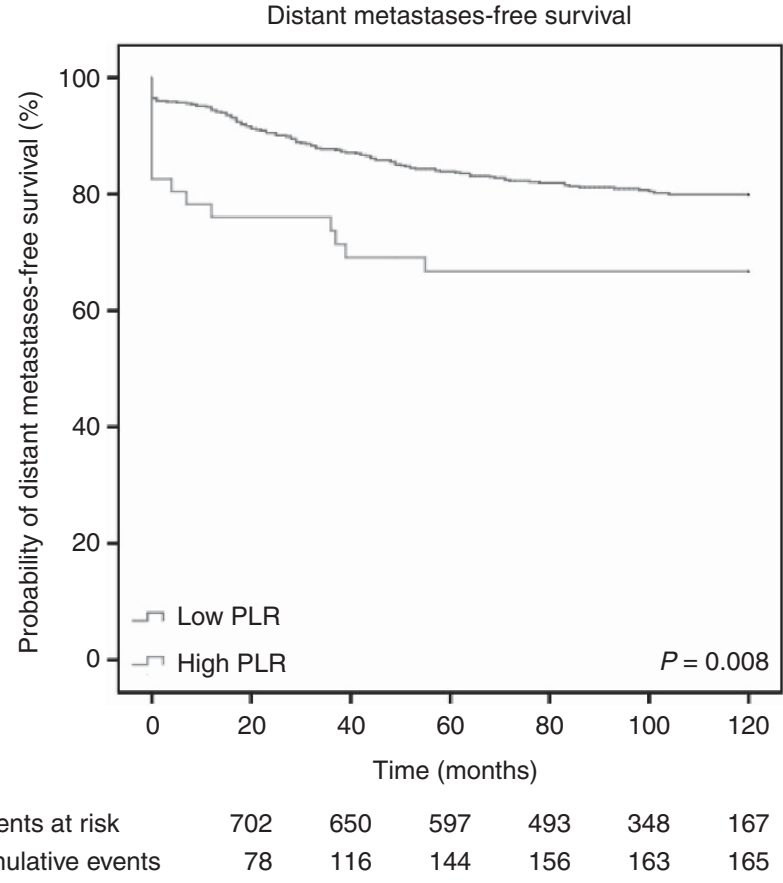

Figure 3. Kaplan-Meier curves for DMFS of breast cancer patients categorised by the PLR.

Recent experimental and clinical data indicate that the activation of platelets is crucial for cancer progression promoting angiogenesis, degradation of the extracellular matrix, and release of adhesion molecules and growth factors (Egan et al, 2011; Kono et al, 2012).

Previous studies have shown a direct correlation between the number of circulating platelets and the level of serum VEGF-A, a major factor in tumour-induced angiogenesis (Benoy et al, 2002). Furthermore, it has been shown that platelets promote invasiveness of tumour cells by enhanced metalloproteinase-9 (MMP-9) secretion and that the addition of anti-platelet drugs may inhibit invasiveness of tumour cells because of decreased MMP-9 secretion (Suzuki et al, 2004).

In addition, numerous studies have suggested that proinflammatory mediators, such as IL-1, IL-3, and IL-6, that are released in various cancer entities stimulate the proliferation of megakaryocytes, the platelet progenitor cells (Klinger and Jelkmann, 2002; Alexandrakis et al, 2003). An increased blood platelet count might therefore also reflect an index of systemic inflammation induced by the tumour.

Lymphocytes have a major role in cancer immunesurveillance, which inhibits tumour cell proliferation and metastasisation (Ownby et al, 1983). Tumour-infiltrating lymphocytes have been linked with improved outcomes in different types of cancer (Ropponen et al, 1997; Mahmoud et al, 2011; West et al, 2011). The peritumoural inflammatory response is thought to reflect the interaction between the tumour and the host. In previous studies, a high lymphocytic infiltrate has been linked with improved survival, independent of clinico-pathological characteristics in primary operable ductal invasive breast cancer (Mohammed et al, 2012). High levels of tumour-infiltrating lymphocytes have also been associated with pathological complete response to primary systemic therapy irrespective of breast cancer subtype (Seo et al, 2013; Dieci et al, 2014). However, data about the correlation of intra-tumoural immune cells and blood-based cells constituting the systemic inflammatory response are sparse.

Previous studies have demonstrated an association between lower peripheral blood lymphocyte count and poor survival in 
Table 2. Univariable and multivariable analysis of clinico-pathological parameters for the prediction of cancer-specific survival in patients with breast cancer $(n=793)$

\begin{tabular}{|c|c|c|c|c|}
\hline & \multicolumn{2}{|c|}{ Univariable analysis } & \multicolumn{2}{|c|}{ Multivariable analysis } \\
\hline & HR $(95 \% \mathrm{Cl})$ & $P$-value & $\operatorname{HR}(95 \% \mathrm{Cl})$ & $P$-value \\
\hline \multicolumn{5}{|c|}{ Age at diagnosis } \\
\hline $\begin{array}{l}<60 \\
\geqslant 60\end{array}$ & $\begin{array}{c}1 \text { (Referent) } \\
0.97 \text { (0.68-1.41) }\end{array}$ & 0.89 & $\begin{array}{c}1 \text { (Referent) } \\
0.97 \text { (0.62-1.50) }\end{array}$ & 0.876 \\
\hline \multicolumn{5}{|c|}{ Tumour stage } \\
\hline $\begin{array}{l}\text { T1 } \\
\text { T2 } \\
\text { T3 } \\
\text { T4 }\end{array}$ & $\begin{array}{c}1 \text { (Referent) } \\
3.31 \text { (2.07-5.30) } \\
3.31 \text { (1.92-5.70) } \\
6.76 \text { (3.48-13.14) }\end{array}$ & $\begin{array}{l}<0.001 \\
<0.001 \\
<0.001\end{array}$ & $\begin{array}{c}1 \text { (Referent) } \\
3.06 \text { (1.79-5.22) } \\
2.35 \text { (1.29-4.27) } \\
3.96 \text { (1.88-8.34) }\end{array}$ & $\begin{array}{r}<0.001 \\
0.005 \\
<0.001\end{array}$ \\
\hline \multicolumn{5}{|c|}{ Lymph node involvement } \\
\hline $\begin{array}{l}\text { N0 } \\
\text { N1 } \\
\text { N2 } \\
\text { N3 }\end{array}$ & \begin{tabular}{|c|}
\multicolumn{1}{c}{1 (Referent) } \\
1.97 (1.26-3.10) \\
$2.66(1.53-4.62)$ \\
5.87 (3.41-10.12)
\end{tabular} & $\begin{array}{r}0.003 \\
0.001 \\
<0.001\end{array}$ & \begin{tabular}{|c|}
\multicolumn{1}{|c|}{1 (Referent) } \\
$1.92(1.12-3.28)$ \\
$1.92(1.02-3.63)$ \\
5.21 (2.71-10.02)
\end{tabular} & $\begin{array}{r}0.017 \\
0.043 \\
<0.001\end{array}$ \\
\hline \multicolumn{5}{|c|}{ Tumour grade } \\
\hline $\begin{array}{l}\text { G1 } \\
\text { G2 } \\
\text { G3 }+4\end{array}$ & \begin{tabular}{|c|}
1 (Referent) \\
1.99 (0.62-6.42) \\
$4.28(1.35-13.60)$
\end{tabular} & $\begin{array}{l}0.251 \\
0.014\end{array}$ & \begin{tabular}{|c|}
1 (Referent) \\
2.06 (0.49-8.74) \\
3.45 (0.82-14.51)
\end{tabular} & $\begin{array}{l}0.328 \\
0.090\end{array}$ \\
\hline \multicolumn{5}{|c|}{ Estrogen receptor } \\
\hline $\begin{array}{l}\text { Negative } \\
\text { Positive }\end{array}$ & $\begin{array}{c}1 \text { (Referent) } \\
0.65 \text { (0.43-0.98) }\end{array}$ & 0.038 & $\begin{array}{c}1 \text { (Referent) } \\
0.90 \text { (0.50-1.61) }\end{array}$ & 0.725 \\
\hline \multicolumn{5}{|c|}{ Progesterone receptor } \\
\hline $\begin{array}{l}\text { Negative } \\
\text { Positive }\end{array}$ & $\begin{array}{c}1 \text { (Referent) } \\
0.74 \text { (0.51-1.07) }\end{array}$ & 0.110 & $\begin{array}{c}1 \text { (Referent) } \\
0.73(0.45-1.19)\end{array}$ & 0.205 \\
\hline \multicolumn{5}{|c|}{ Her2 status } \\
\hline $\begin{array}{l}\text { Negative } \\
\text { Positive }\end{array}$ & $\begin{array}{c}1 \text { (Referent) } \\
1.24(0.75-2.06)\end{array}$ & 0.402 & $\begin{array}{c}1 \text { (Referent) } \\
0.79 \text { (0.44-1.42) }\end{array}$ & 0.426 \\
\hline \multicolumn{5}{|c|}{ Platelet-to-lymphocyte ratio } \\
\hline $\begin{array}{l}<292 \\
\geqslant 292\end{array}$ & $\begin{array}{c}1 \text { (Referent) } \\
2.75(1.57-4.83)\end{array}$ & $<0.001$ & $\begin{array}{c}1 \text { (Referent) } \\
2.03 \text { (1.03-4.02) }\end{array}$ & 0.042 \\
\hline
\end{tabular}

different types of cancer (Fogar et al, 2006; Ray-Coquard et al, 2009). Azab et al (2013)showed an improved survival in breast cancer patients with elevated lymphocyte counts compared with those with lower lymphocyte counts.

Furthermore, previous studies demonstrated that normalisation of an initial lymphocytopenia resulted in an improved clinical outcome in breast cancer patients treated with chemotherapy (Nieto et al, 2004; West et al, 2011). An elevated lymphocyte count has also significantly been associated with prolonged OS in patients with multiple myeloma and metastatic colorectal cancer (Leitch et al, 2007; Ege et al, 2008).

A combined index using platelet and lymphocyte counts has been investigated as prognostic marker for different cancer entities. In advanced gastric cancer patients, Lee et al (2012) demonstrated that an elevated PLR is associated with worse OS. A poor prognostic impact of an elevated PLR has also been demonstrated in ovarian cancer and pancreatic cancer (Smith et al, 2009;
Table 3. Univariable and multivariable analysis of the platelet-tolymphocyte ratio (PLR) for the prediction of cancer-specific survival in different breast cancer subtypes $(n=720)$

\begin{tabular}{|c|c|c|c|c|}
\hline & \multicolumn{2}{|c|}{ Univariable analysis } & \multicolumn{2}{|c|}{ Multivariable analysis $^{a}$} \\
\hline & HR $(95 \% \mathrm{Cl})$ & $P$-value & $\mathrm{HR}(95 \% \mathrm{Cl})$ & $P$-value \\
\hline \multicolumn{5}{|c|}{ Luminal A } \\
\hline $\begin{array}{l}P L R \leqslant 292 \\
P L R \geqslant 292\end{array}$ & $\begin{array}{c}1 \text { (Referent) } \\
1.14(0.27-4.71)\end{array}$ & 0.86 & $\begin{array}{c}1 \text { (Referent) } \\
1.44(0.32-6.43)\end{array}$ & 0.65 \\
\hline \multicolumn{5}{|l|}{ Luminal B } \\
\hline $\begin{array}{l}P L R \leqslant 292 \\
P L R \geqslant 292\end{array}$ & $\begin{array}{c}1 \text { (Referent) } \\
2.78 \text { (1.31-5.91) }\end{array}$ & 0.008 & $\begin{array}{c}1 \text { (Referent) } \\
2.54 \text { (1.04-6.18) }\end{array}$ & 0.04 \\
\hline \multicolumn{5}{|l|}{ Basal like } \\
\hline $\begin{array}{l}P L R \leqslant 292 \\
P L R \geqslant 292\end{array}$ & $\begin{array}{c}1 \text { (Referent) } \\
8.49(2.22-32.47)\end{array}$ & 0.002 & $\begin{array}{c}1 \text { (Referent) } \\
3.90(0.62-24.32)\end{array}$ & 0.15 \\
\hline \multicolumn{5}{|l|}{ Her2 } \\
\hline $\begin{array}{l}P L R \leqslant 292 \\
P L R \geqslant 292\end{array}$ & $\begin{array}{c}1 \text { (Referent) } \\
\text { NA }\end{array}$ & 0.665 & $\begin{array}{c}1 \text { (Referent) } \\
\text { NA }\end{array}$ & 0.977 \\
\hline
\end{tabular}

Table 4. Univariable and multivariable analysis of clinico-pathological parameters for the prediction of cancer-specific survival in luminal $B$ breast cancer patients $(n=251)$

\begin{tabular}{|c|c|c|c|c|}
\hline & \multicolumn{2}{|c|}{ Univariable analysis } & \multicolumn{2}{|c|}{ Multivariable analysis $^{a}$} \\
\hline & $\mathrm{HR}(95 \% \mathrm{Cl})$ & $P$-value & HR $(95 \% \mathrm{Cl})$ & $P$-value \\
\hline \multicolumn{5}{|c|}{ Age at diagnosis } \\
\hline $\begin{array}{l}<60 \\
\geqslant 60\end{array}$ & $\begin{array}{c}1 \text { (Referent) } \\
1.120(0.661-1.897)\end{array}$ & 0.675 & $\begin{array}{c}1 \text { (Referent) } \\
1.212(0.647-2.271)\end{array}$ & 0.549 \\
\hline \multicolumn{5}{|c|}{ Tumour stage } \\
\hline $\begin{array}{l}\text { T1 } \\
\text { T2 } \\
\text { T3 } \\
\text { T4 }\end{array}$ & $\begin{array}{c}1 \text { (Referent) } \\
2.221(1.154-4.275) \\
1.840(0.842-4.019) \\
3.929(1.544-9.997)\end{array}$ & $\begin{array}{l}0.017 \\
0.126 \\
0.004\end{array}$ & $\begin{array}{c}1 \text { (Referent) } \\
1.749(0.841-3.637) \\
1.420(0.619-3.258) \\
2.825(0.994-8.031)\end{array}$ & $\begin{array}{l}0.134 \\
0.408 \\
0.051\end{array}$ \\
\hline \multicolumn{5}{|c|}{ Lymph node involvement } \\
\hline $\begin{array}{l}\text { N0 } \\
\text { N1 } \\
\text { N2 } \\
\text { N3 }\end{array}$ & \begin{tabular}{l}
\multicolumn{1}{c}{1 (Referent) } \\
$2.199(1.117-4.329)$ \\
$1.626(0.689-3.836)$ \\
$8.228(3.835-17.653)$
\end{tabular} & $\begin{array}{r}0.023 \\
0.267 \\
<0.001\end{array}$ & \begin{tabular}{|c|}
1 (Referent) \\
$2.069(0.950-4.509)$ \\
$1.632(0.652-4.084)$ \\
$7.969(3.371-18.837)$
\end{tabular} & $\begin{array}{r}0.067 \\
0.295 \\
<0.001\end{array}$ \\
\hline \multicolumn{5}{|l|}{ PLR } \\
\hline $\begin{array}{l}P L R \leqslant 292 \\
P L R \geqslant 292\end{array}$ & $\begin{array}{c}1 \text { (Referent) } \\
2.780(1.308-5.910)\end{array}$ & 0.008 & $\begin{array}{c}1 \text { (Referent) } \\
2.538(1.043-6.177)\end{array}$ & 0.040 \\
\hline $\begin{array}{l}\text { Abbreviatior } \\
\text { ratio. } \\
{ }^{\text {a }} \text { Adjustmen }\end{array}$ & $\begin{array}{l}\mathrm{Cl}=\text { confidence interval } \\
\text { or all factors listed in the }\end{array}$ & $\begin{array}{l}\text { HR }=\text { hazar } \\
\text { table. }\end{array}$ & d ratio; $P L R=$ platelet-to & -lymphocyte \\
\hline
\end{tabular}

Asher et al, 2011; Raungkaewmanee et al, 2012). Furthermore, recent studies have shown a significant association between an elevated PLR and decreased OS after curative resection of colorectal cancer (Kwon et al, 2012; Liu et al, 2013). 
In breast cancer, Seretis et al (2012) found a correlation between an elevated PLR and the number of infiltrated lymph nodes. More recently, Azab et al (2013) studied the impact of the PLR on OS in 437 breast cancer patients. The authors categorised the included patients according to PLR quartiles and found that patients in the highest PLR quartile had a significant higher 5-year mortality rate (Azab et al, 2013).

In breast cancer patients, elevated inflammatory markers such as C-reactive protein, serum amyloid A, and serum IL-6 have also been associated with reduced survival (Bachelot et al, 2003; Pierce et al, 2009). Furthermore, the measurement of the systemic inflammatory response using a selective combination of C-reactive protein and albumin (termed the modified Glasgow prognostic score) has been shown to have prognostic value in different cancer entities including breast cancer (Proctor et al, 2011). Besides PLR, other pre-therapeutic indices of systemic inflammation such as NLR and the lymphocyte-to-monocyte ratio have been suggested to provide prognostic information in different cancer entities (Azab et al, 2013; Stotz et al, 2014).

Azab et al (2013) have also shown a significant association of the pretreatment NLR with mortality that was superior to the prognostic effect of PLR. However, the authors have only analysed OS but not CSS, which might be influenced by numerous other factors including non-cancer-related deaths. In the present study, we did not detect a significant impact of an elevated NLR on CSS in multivariable analysis. Our findings are consistent with the data previously reported by Smith et al (2009) who found that PLR, not NLR, was a predictor of mortality in pancreatic cancer. Furthermore, Asher et al (2011) demonstrated that elevated PLR, not NLR, was a predictor of poor survival among patients with ovarian cancer. In a study by Kwon et al (2012), the elevated PLR, not NLR, has been shown to be a significant predictor of mortality in 200 colorectal cancer patients.

In the present study, an elevated preoperative PLR was significantly associated with decreased CSS and OS in breast cancer patients. These statistical associations retained their significance after adjusting for other potential predictors of patients' outcome and were independent of patient age, $\mathrm{T}$ - and $\mathrm{N}$-stage, tumour grade, and ER, PR, and Her2 status.

Our findings indicate that an elevated PLR might be a poor prognostic factor in breast cancer patients. Patients with an elevated PLR might be considered as candidates for additional, more aggressive treatment approaches or more stringent follow-up schedules. The results of subgroup analysis indicate that the preoperative PLR carried the most significant prognostic information in patients with luminal B tumours. In this subgroup, the impact of the PLR on CSS turned out to be superior when compared with age, $\mathrm{T}$ status, and $\mathrm{N} 1$ and $\mathrm{N} 2$ status, and might contribute to the identification of patients who would benefit from a more aggressive treatment approach. If the present findings are replicated in future studies, determination of the PLR may help to obtain a more precise individual risk profile for breast cancer mortality and contribute to a tailored treatment of breast cancer patients.

However, our data have to be regarded as preliminary and have to be interpreted cautiously until validated by additional studies. Confirmation of the present results in an independent data set is imperative to draw firm conclusions about the role of PLR for breast cancer prognosis.

Major strengths of our study include the relatively large sample size and the narrow time frame for blood collection within 3 days before surgery excluding possible clinically significant infections.

However, as with all retrospective studies, limitations of our study are inherent to its design including the retrospective data collection. In addition, it has to be taken into account that lymphocyte and platelet counts may be influenced by several other conditions or factors. Increased platelet counts are often caused by inflammatory diseases, such as connective tissue disorders, medication, bacterial diseases, or viral infections. The most common cause of low lymphocyte counts is a recent infection. In addition, lymphocytopenia may also be caused by infections, malnutrition, connective tissue disorders, severe stress, intense physical exercise, and medical treatments. Nevertheless, even considering these limitations, our data indicate that an increased preoperative PLR might represent an independent prognostic factor for CSS and OS in non-metastatic breast cancer patients.

In conclusion, an increased preoperative PLR seems to significantly affect CSS and OS in non-metastatic breast cancer patients and may support oncological therapy decisions. Clarifying the optimal PLR cutoff level and independent validation of our findings is warranted.

CONFLICT OF INTEREST

The authors declare no conflict of interest.

\section{REFERENCES}

Absenger G, Szkandera J, Pichler M, Stotz M, Arminger F, Weissmueller M, Schaberl-Moser R, Samonigg H, Stojakovic T, Gerger A (2013) A derived neutrophil to lymphocyte ratio predicts clinical outcome in stage II and III colon cancer patients. Br J Cancer 109: 395-400.

Albain KS, Barlow WE, Shak S, Hortobagyi GN, Livingston RB, Yeh IT, Ravdin P, Bugarini R, Baehner FL, Davidson NE, Sledge GW, Winer EP, Hudis C, Ingle JN, Perez EA, Pritchard KI, Shepherd L, Gralow JR, Yoshizawa C, Allred DC, Osborne CK, Hayes DF (2010) Prognostic and predictive value of the 21-gene recurrence score assay in postmenopausal women with nodepositive, oestrogen-receptor-positive breast cancer on chemotherapy: a retrospective analysis of a randomised trial. Lancet Oncol 11: 55-65.

Alexandrakis MG, Passam FH, Moschandrea IA, Christophoridou AV, Pappa CA, Coulocheri SA, Kyriakou DS (2003) Levels of serum cytokines and acute phase proteins in patients with essential and cancer-related thrombocytosis. Am J Clin Oncol 26: 135-140.

Asher V, Lee J, Innamaa A, Bali A (2011) Preoperative platelet lymphocyte ratio as an independent prognostic marker in ovarian cancer. Clin Transl Oncol 13: 499-503.

Azab B, Shah N, Radbel J, Tan P, Bhatt V, Vonfrolio S, Habeshy A, Picon A, Bloom S (2013) Pretreatment neutrophil/lymphocyte ratio is superior to platelet/lymphocyte ratio as a predictor of long-term mortality in breast cancer patients. Med Oncol 30: 432.

Bachelot T, Ray-Coquard I, Menetrier-Caux C, Rastkha M, Duc A, Blay JY (2003) Prognostic value of serum levels of interleukin 6 and of serum and plasma levels of vascular endothelial growth factor in hormone-refractory metastatic breast cancer patients. Br J Cancer 88: 1721-1726.

Balkwill F, Mantovani A (2001) Inflammation and cancer: back to Virchow? Lancet 357: 539-545.

Benoy I, Salgado R, Colpaert C, Weytjens R, Vermeulen PB, Dirix LY (2002) Serum interleukin 6, plasma VEGF, serum VEGF, and VEGF platelet load in breast cancer patients. Clin Breast Cancer 2: 311-315.

Blamey RW, Ellis IO, Pinder SE, Lee AH, Macmillan RD, Morgan DA, Robertson JF, Mitchell MJ, Ball GR, Haybittle JL, Elston CW (2007) Survival of invasive breast cancer according to the Nottingham Prognostic Index in cases diagnosed in 1990-1999. Eur J Cancer 43: 1548-1555.

Carruthers R, Tho LM, Brown J, Kakumanu S, McCartney E, McDonald AC (2012) Systemic inflammatory response is a predictor of outcome in patients undergoing preoperative chemoradiation for locally advanced rectal cancer. Colorectal Dis 14: 701-707.

Coussens LM, Werb Z (2002) Inflammation and cancer. Nature 420: 860-867.

Dethlefsen C, Højfeldt G, Hojman P (2013) The role of intratumoral and systemic IL-6 in breast cancer. Breast Cancer Res Treat 138: 657-664.

Dieci MV, Criscitiello C, Goubar A, Viale G, Conte P, Guarneri V, Ficarra G, Mathieu MC, Delaloge S, Curigliano G, Andre F (2014) Prognostic value of tumor-infiltrating lymphocytes on residual disease after primary chemotherapy for triple-negative breast cancer: a retrospective multicenter study. Ann Oncol 25: 611-618.

Drukker CA, Bueno-de-Mesquita JM, Retèl VP, van Harten WH, van Tinteren H, Wesseling J, Roumen RM, Knauer M, van 't Veer LJ, Sonke GS, Rutgers EJ, van de Vijver MJ, Linn SC (2013) A prospective evaluation of a breast 
cancer prognosis signature in the observational RASTER study. Int $J$ Cancer 133: 929-936.

Egan K, Crowley D, Smyth P, O'Toole S, Spillane C, Martin C, Gallagher M, Canney A, Norris L, Conlon N, McEvoy L, Ffrench B, Stordal B, Keegan H, Finn S, McEneaney V, Laios A, Ducrée J, Dunne E, Smith L, Berndt M, Sheils O, Kenny D, O'Leary J (2011) Platelet adhesion and degranulation induce pro-survival and pro-angiogenic signalling in ovarian cancer cells. PLoS One 6: e26125.

Ege H, Gertz MA, Markovic SN, Lacy MQ, Dispenzieri A, Hayman SR, Kumar SK, Porrata LF (2008) Prediction of survival using absolute lymphocyte count for newly diagnosed patients with multiple myeloma: a retrospective study. Br J Haematol 141: 792-798.

Ferlay J, Steliarova-Foucher E, Lortet-Tieulent J, Rosso S, Coebergh JW, Comber H, Forman D, Bray F (2012) Cancer incidence and mortality patterns in Europe: estimates for 40 countries in 2012. Eur J Cancer 49: 1374-1403.

Fogar P, Sperti C, Basso D, Sanzari MC, Greco E, Davoli C, Navaglia F, Zambon CF, Pasquali C, Venza E, Pedrazzoli S, Plebani M (2006) Decreased total lymphocyte counts in pancreatic cancer: an index of adverse outcome. Pancreas 32: 22-28.

Goldhirsch A, Wood WC, Coates AS, Gelber RD, Thürlimann B, Senn HJ. Panel members (2011) Strategies for subtypes-dealing with the diversity of breast cancer: highlights of the St Gallen International Expert Consensus on the Primary Therapy of Early Breast Cancer 2011. Ann Oncol Aug 22: 1736-1747.

He W, Yin C, Guo G, Jiang C, Wang F, Qiu H, Chen X, Rong R, Zhang B, Xia L (2013) Initial neutrophil lymphocyte ratio is superior to platelet lymphocyte ratio as an adverse prognostic and predictive factor in metastatic colorectal cancer. Med Oncol 30: 439.

Klinger MH, Jelkmann W (2002) Role of blood platelets in infection and inflammation. J Interferon Cytokine Res 22: 913-922.

Koch A, Fohlin H, Sörenson S (2009) Prognostic significance of C-reactive protein and smoking in patients with advanced non-small cell lung cancer treated with first-line palliative chemotherapy. J Thorac Oncol 4: 326-332.

Kono SA, Heasley LE, Doebele RC, Camidge DR (2012) Adding to the mix: fibroblast growth factor and platelet-derived growth factor receptor pathways as targets in non-small cell lung cancer. Curr Cancer Drug Targets 12: 107-123.

Kraeima J, Siesling S, Vliegen IM, Klaase JM, Ijzerman MJ (2013) Individual risk profiling for breast cancer recurrence: towards tailored follow-up schemes. Br J Cancer 109: 866-871.

Kwon HC, Kim SH, Oh SY, Lee S, Lee JH, Choi HJ, Park KJ, Roh MS, Kim SG, Kim HJ, Lee JH (2012) Clinical significance of preoperative neutrophillymphocyte versus platelet-lymphocyte ratio in patients with operable colorectal cancer. Biomarkers 17: 216-222.

Lee S, Oh SY, Kim SH, Lee JH, Kim MC, Kim KH, Kim HJ (2012) Pretreatment neutrophil:lymphocyte ratio as a prognostic factor in cervical carcinoma. BMC Cancer 13: 350.

Leitch EF, Chakrabarti M, Crozier JE, McKee RF, Anderson JH, Horgan PG, McMillan DC (2007) Comparison of the prognostic value of selected markers of the systemic inflammatory response in patients with colorectal cancer. Br J Cancer 97: 1266-1270.

Liu HL, DU XH, Sun PM, Xiao CH, Xu YX, Li R (2013) Preoperative plateletlymphocyte ratio is an independent prognostic factor for resectable colorectal cancer. Nan Fang Yi Ke Da Xue Xue Bao 33: 70-73.

Mahmoud SM, Paish EC, Powe DG, Macmillan RD, Grainge MJ, Lee AH, Ellis IO, Green AR (2011) Tumor-infiltrating CD8 + lymphocytes predict clinical outcome in breast cancer. J Clin Oncol 29: 1949-1955.

Mantovani A, Allavena P, Sica A, Balkwill F (2008) Cancer-related inflammation. Nature 454: 436-444.

Mohammed ZMA, Going JJ, Edwards J, Elsberger B, Doughty JC, McMillan DC (2012) The relationship between components of tumour inflammatory cell infiltrate and clinicopathological factors and survival in patients with primary operable invasive ductal breast cancer. Br J Cancer 107: 864-873.

Nieto Y, Nawaz S, Shpall EJ, Bearman SI, Murphy J, Jones RB (2004) Long-term analysis and prospective validation of a prognostic model for patients with high-risk primary breast cancer receiving high-dose chemotherapy. Clin Cancer Res 10: 2609-2617.
Ownby HE, Roi LD, Isenberg RR, Brennan MJ (1983) Peripheral lymphocyte and eosinophil counts as indicators of prognosis in primary breast cancer. Cancer 52: 126-130.

Pierce BL, Ballard-Barbash R, Berstein L, Baumgartner RN, Neuhouser ML, Wener MH, Baumgartner KB, Gilliland FD, Sorensen BE, McTiernan A, Ulrich CM (2009) Elevated biomarkers of inflammation are associated with reduced survival among breast cancer patients. J Clin Oncol 21: 3437-3444.

Proctor MJ, Morrison DS, Talwar D, Balmer SM, Fletcher CD, O’Reilly DS, Foulis AK, Horgan PG, McMillan DC (2011) A comparison of inflammation-based prognostic scores in patients with cancer. A Glasgow Inflammation Outcome Study. Eur J Cancer 47: 2633-2641.

Raungkaewmanee S, Tangjitgamol S, Manusirivithaya S, Srijaipracharoen S, Thavaramara T (2012) Platelet to lymphocyte ratio as a prognostic factor for epithelial ovarian cancer. J Gynecol Oncol 23: 265-273.

Ray-Coquard I, Cropet C, Van Glabbeke M, Sebban C, Le Cesne A, Judson I, Tredan O, Verweij J, Biron P, Labidi I, Guastalla JP, Bachelot T, Perol D, Chabaud S, Hogendoorn PC, Cassier P, Dufresne A, Blay JY (2009) European Organization for Research and Treatment of Cancer Soft Tissue and Bone Sarcoma Group. Lymphopenia as a prognostic factor for overall survival in advanced carcinomas, sarcomas, and lymphomas. Cancer Res 69: $5383-5391$.

Ropponen KM, Eskelinen MJ, Lipponen PK, Alhava E, Kosma VM (1997) Prognostic value of tumour-infiltrating lymphocytes (TILs) in colorectal cancer. J Pathol 182: 318-324.

Roxburgh CS, McMillan DC (2012) The role of the in situ local inflammatory response in predicting recurrence and survival in patients with primary operable colorectal cancer. Cancer Treat Rev 38: 451-466.

Saghatchian M, Mook S, Pruneri G, Viale G, Glas AM, Guerin S, Cardoso F, Piccart M, Tursz T, Delaloge S, Van’t Veer L (2012) Additional prognostic value of the 70 -gene signature (MammaPrint $(\AA))$ among breast cancer patients with 4-9 positive lymph nodes. Breast 22: 682-690.

Salazar-Onfray F, Lopez MN, Mendoza-Naranjo A (2007) Paradoxical effects of cytokines in tumor immune surveillance and tumor escape. Cytokine Growth Factor Rev 18: 171-182.

Seo AN, Lee HJ, Kim EJ, Kim HJ, Jang MH, Lee HE, Kim YJ, Kim JH, Park SY (2013) Tumour-infiltrating CD8 + lymphocytes as an independent predictive factor for pathological complete response to primary systemic therapy in breast cancer. Br J Cancer 109: 2705-2713.

Seretis C, Seretis F, Lagoudianakis E, Politou M, Gemenetzis G, Salemis NS (2012) Enhancing the accuracy of platelet to lymphocyte ratio after adjustment for large platelet count: a pilot study in breast cancer patients. Int J Surg Oncol 2012: 653608.

Smith RA, Bosonnet L, Raraty M, Sutton R, Neoptolemos JP, Campbell F, Ghaneh P (2009) Preoperative platelet-lymphocyte ratio is an independent significant prognostic marker in resected pancreatic ductal adenocarcinoma. Am J Surg 197: 466-472.

Smith RA, Ghaneh P, Sutton R, Raraty M, Campbell F, Neoptolemos JP (2008) Prognosis of resected ampullary adenocarcinoma by preoperative serum CA19-9 levels and platelet-lymphocyte ratio. J Gastrointest Surg 12: 1422-1428.

Stotz M, Pichler M, Absenger G, Szkandera J, Arminger F, Schaberl-Moser R, Samonigg H, Stojakovic T, Gerger A (2014) The preoperative lymphocyte to monocyte ratio predicts clinical outcome in patients with stage III colon cancer. Br J Cancer 110: 435-440.

Suzuki K, Aiura K, Ueda M, Kitajima M (2004) The influence of platelets on the promotion of invasion by tumor cells and inhibition by antiplatelet agents. Pancreas 29: 132-140.

Szkandera J, Gerger A, Liegl-Atzwanger B, Absenger G, Stotz M, Samonigg H, Maurer-Ertl W, Stojakovic T, Ploner F, Leithner A, Pichler M (2013) Validation of the prognostic relevance of plasma C-reactive protein levels in soft-tissue sarcoma patients. Br J Cancer 109: 2316-2322.

West NR, Milne K, Truong PT, Macpherson N, Nelson BH, Watson PH (2011) Tumor-infiltrating lymphocytes predict response to anthracyclinebased chemotherapy in estrogen receptor-negative breast cancer. Breast Cancer Res 13: R126.

This work is published under the standard license to publish agreement. After 12 months the work will become freely available and the license terms will switch to a Creative Commons AttributionNonCommercial-Share Alike 3.0 Unported License.

\section{Supplementary Information accompanies this paper on British Journal of Cancer website (http://www.nature.com/bjc)}

